\title{
Bolei Liu
}

Columbia University, U.S.A.

\section{Getting a Job in Flushing: A Qualitative Study on Chinese Immigrants' Job-Finding and Job Transitions} in an Ethnic Enclave

DOI: https://doi.org/10.18778/1733-8077.13.2.05

Abstract In this study, I investigated how different forms of human capital and social capital of new Chinese immigrants affect their job-search and job transitions in the Flushing area. I conducted sixteen indepth interviews with new Chinese immigrants who were seeking job opportunities within Flushing, documenting not only their personal background but also their immigration and working experiences in both China and the United States. Results indicate that the aggregation of certain human capital has positive influence on immigrants' income, rather on immigrants' job-findings and job transitions. The efficiency of social ties, instead of strength of social ties, is a more significant unit of analysis in the co-ethnic labor market. Though immigrants' efficient social ties may be helpful for finding their first jobs in the U.S., the efficiency of social ties with regards to job-searching may dramatically decrease as immigrants stay longer in the U.S. As a result, social ties may not have a salient influence on immigrants' job transitions.

Keywords Immigration Studies; Labor Market; Human Capital; Social Capital; Ethnography

It's different if you want to find a job in the U.S. I mean, I would also wanted to be a driver in the United States, but my parents could not provide me such a job here, and I don't have legal status. No American people would like to hire an undocumented Chinese immigrant to drive for them. Without SSN, they won't trust you at all. Even if there is such a miracle that

Bolei Liu is a Master's student in the Department of Sociology at Columbia University. His research interests lie in economic sociology, labor market, and immigration studies.

email address: bl2519@columbia.edu
I got the same job as I had in China, could I communicate with my boss? I probably wouldn't even understand where he wanted to go, and let alone to be a close friend to him. Such a guy who has no English proficiency, no legal status, no citizenship, you have no rights to choose your job. Somehow, it is the job that chooses [sic] you.

The above is an excerpt from an interview with 1 Kwong. When Kwong was 17 years old, after graduating from junior high school in China, Kwong's father, a local government official, offered him a full-time driving job at a large state-owned company in China. A few years later, Kwong became a private driver for the president of the company, and because of this intimate relationship, even vice presidents in the company had to be respectful to Kwong, since, according to Kwong, "they regarded me as a big character, as well and were afraid that I would speak something bad of them to my boss." Sometimes other employees would even bribe Kwong for promotion in the company. Kwong's parents migrated to the U.S. in 1998, and although they still did not have a legal immigration status, Kwong's parents rented a piece of farmland in New Jersey. They thought that even agricultural work in the U.S. was more lucrative than working in a secondary city in China, and their only hope was that their children could reunite with them. Therefore, Kwong, with his wife and son, finally moved into the United States in 2010. However, when Kwong and his family eventually reunited in the United States and lived there for several years, Kwong realized that the United States was not "the promised land" for him. The quondam "big character" now is washing dishes and cleaning tables in a Chinese restaurant in Flushing for twelve hours a day.

In Flushing, Kwong is not alone. Tens of thousands of new Chinese immigrants flock into the Chinese community within Flushing every year (Zhou 1992; 2009; Wong 1998; Lim 2013), and as of 2010, there were 71,601 documented Chinese living in Flushing, which accounted for $28.5 \%$ of the entire population in that area. Besides them, there are undocumented immigrants who entered the U.S. with their tourist visas and decided to stay in the U.S. for a longer time to earn money. Most of the newcomers, like Kwong, lack elementary English language skills and legal immigration status (Tsai 2009; Lim 2013).
The enclosed environment to outside economy and the self-sufficiency of ethnic economy in Chinese ethnic enclaves provide immigrants with more business opportunities among their co-ethnic group, which also creates job opportunities for newcomers. For these newcomers, ethnic enclaves are not only temporary shelters upon arrival but also places in which they can securely earn a living. However, facing the same problems with Kwong, newcomers must engage in brand new job opportunities, most of which are beyond their imaginations from when they were in China.

The industries in Flushing are mostly service-oriented, such as restaurants, supermarkets, interior design and construction, logistics, and beauty salons (Wong 1998; Chua 2002; Chin 2005; Tsai 2009; Zhou 2009). This variety of businesses provides immigrants with abundant job opportunities, yet these positions are invariably service-oriented lowend occupations paying nearly minimum wage and with long working hours (Zhou 1992; Tsai 2009). Yet, although with this inferior wage and working conditions, the competition for these positions is still fierce in the labor market (Zhou 2009; Lim 2013).

As Kwong stated in the above excerpt, immigrants without English proficiency, legal status, and social ties seem to be at a disadvantage with those who have stronger human and social capital in the ethnic labor market, similar to the job-finding and job transitions process in the primary labor market outside of the ethnic enclave. However, there are some particularities of the Chinese ethnic labor market that emerged in my research, specifically that stronger human capital does not necessarily amount to easier 
job-finding, and the strength of social ties (strong ties or weak ties) (Granovetter 1973; 1995) may not be an indicator of the ease of job-finding and job transitions in the Chinese ethnic labor market.

\section{Theoretical Framework and Literature Review}

\section{The Ethnic Enclave and Enclave Economy}

In the last few decades, the ethnic enclave is one of the most crucial topics in the research on immigration issues. Scholars focus on the relation between earnings and human and social capital of immigrants in host countries. Most of them believe that the human capital and social capital would be the primary predictors of immigrants' earnings in labor market (Becker 1962), but they have different opinions on the relationship between co-ethnic environments and immigrants' well-being. Portes found that immigrant workers in the enclave labor market achieve greater returns on human capital than those who participate in the outside economy (Wilson and Portes 1980; Portes and Bach 1985; Zhou and Logan 1989; Waldinger 1993). However, Sanders and Nee (1987) suggest that as long as immigrants lack the cultural and language skills of the host country, their employment opportunities are usually limited to relatively poor paying jobs. Zhou and Logan (1989) point out that among New York's Chinese immigrants, some enclave workers are able to take advantage of specific forms of human capital (college education and English language ability) to increase earnings, and their empirical research reveals that the absolute earning gap between workers (both male and female) within and outside ethnic enclave is large: enclave workers have worse jobs at lower pay than those outside of the enclave.

The ethnic economy theory discusses the economy's role in immigrants' welfare. The discussion mainly explores the reasons why ethnic labor market affects immigrants' well-being differently. On the one hand, some research suggest that the ethnic enclave opens opportunities for its members which were not easily obtained in larger society, and shelters immigrants from discrimination and government regulation (Wilson and Portes 1980; Portes and Bach 1985; Zhou and Logan 1989; Zhou 1992; 2009; Bates 1994; Lin 1998; Xie and Gough 2011). The shelter effect of the ethnic enclave mainly refers to the co-ethnic environment, which reduces the barriers such as English language skill and different customs that immigrants may face in the mainstream labor market (Zhou and Logan 1989; Bates 1994; Nee, Sanders, and Sernau 1994; Chua 2002)

On the other hand, the co-ethnic environment also, to some extent, constrains immigrants' mobility in labor market and leads to exploitation of immigrants (Sanders and Nee 1987; Bonacich 1988; Zhou and Logan 1989; Bailey and Waldinger 1991; Zhou 1992; Bohon 2001). One interpretation of this finding is that the industries in the ethnic enclave are mainly labor-intensive and low-skilled oriented, which requires a large number of cheap laborers and merely basic professional skills. Low-skilled immigrants rarely accumulate human capital in such an environment and, unfortunately, are often trapped in it (Bohon 2001; Zhou 2009).
The ethnic economy theory delineates the meaning of low-skilled labor market to low-skilled immigrants. This theory implies that the ethnic lowskilled labor market, on the one hand, might be a shelter for immigrants through avoiding competition with White and other minority laborers, but on the other hand, probably restrains immigrants' mobilization through requiring low-skilled immigrants to perform low-skilled work and earn low wages. Applying the ethnic economy theory to analyze low-skilled immigrants' job-finding may explain why low-skilled immigrants prefer to find jobs in a co-ethnic environment, and the characteristics of low-skilled immigrants' potential job opportunities in the low-skilled labor market.

\section{Low Wages and Labor Markets}

A fair numbers of researchers attribute immigrant workers' low wages to their human capital and social capital (Phillips and Massey 1999; Carnevale and Rose 2001; Pérez and Muñoz 2001; Logan, Zhang, and Alba 2002; Maxwell 2008). Logan and colleagues (2002) compared immigrants' data from New York and Los Angeles and found that in an ethnic community, residents are more likely to have less human capital, such as foreign birth, limited English language facility, and fewer years of education. Pérez and Muñoz (2001), in their research on low wage Latino workers, argue that for any worker education is the most significant human capital predictor of earnings and labor market success, and they also suggest that specific skills are an important indicator of high-paying jobs. Carnevale and Rose (2001) also consider education to be of great importance for the success in the la- bor market. Phillips and Massey (1999) discussed in detail the human capital and social capital of immigrants. Through their research on Mexican immigrants, they summarized the general pattern of the relation between immigrants' wage and their human and social capital, and found that wages are determined primarily by human capital and to a lesser extent by social capital, and increase with education, English language ability, and U.S. job experience. However, legal status did not have much significant influence on the wages of low income immigrants.

\section{Human Capital and Social Ties}

The discussion of human capital mostly revolves around how human capital affects the wage of individuals, and specifically, immigrants (Becker 1962; Coleman 1988; Zhou 1992; Nee, Sanders, and Sernau 1994; Hagan, Lowe, and Quingla 2011; Mane and Waldorf 2013). Generally, higher human capital indicates higher wages in the labor market (Becker 1962; Bohon 2001; Zhou 2009). Some researchers have noticed the discrepancy between human capital that was acquired in the country of origins and that was acquired in receiving countries, and they argue that the transferability of human capital determines the effects of human capital in the receiving countries (Friedberg 2000; Mane and Waldorf 2013). Other studies find that some forms of human capital, such as English proficiency and educational attainment, have a significant influence on immigrants' wages and mobility in the labor market (Portes and Bach 1985; Zhou and Logan 1989; Zhou 1992; Nee, Sanders, and Sernau 1994; Sanders, Nee, and Sernau 2002). Social capital theory mainly 
focuses on the social ties of immigrants in new labor markets, and how immigrants find their jobs in new environments through their social ties. A prevailing assumption of social capital theory is that social ties are vital resources which enable immigrants to find their economic and social niches in host countries. In other words, social capital is a key factor in immigrant's assimilation process (Sanders, Nee, and Sernau 2002).

Social ties, as a principal component of social capital, are especially significant for low-skilled immigrants, and their social networks play a significant role in the matching and sorting of immigrants to potential jobs in receiving societies (Bailey and Waldinger 1991) and in establishing the basis for mutual trust and cooperation (Portes and Sensenbrenner 1993). This mutual trust and cooperation between immigrants and their contacts, which facilitate the sharing of resources such as the dissemination of information to help people obtain employment, can strongly affect the well-being of immigrants and the development of ethnic enterprises (Portes and Bach 1985; Light and Banacich 1988; Sanders, Nee, and Sernau 2002). Immigrants' social networks are largely based on family and ethnic ties, which constitute the social capital that immigrants can draw on to improve their economic and social status (Sanders and Nee 1996; Sanders, Nee, and Sernau 2002).

Granovetter has found that people in labor markets have either formal or informal ways of finding a job, and they usually rely on their informal individual contacts rather than formal channels. Granovetter $(1973 ; 1995)$ illustrates that the strength of interper- sonal ties have a strong influence on immigrants job-finding, and it is usually acquaintances (weak ties) rather than family or close friends that serve as bridges between networks, since strong ties are regarded as belonging to similar networks with access to comparable resources as the subjects' own networks. However, other thinkers believe that merely analyzing the strength of ties is pointless, and filling and bridging the structural gaps between different networks are more important (Burt 1992). In an immigration context, the theory of weak ties is not as convincing as the theory of structural gaps, since immigrants' networks are dramatically changed as they immigrate into a new environment, and are different from the research subjects of Granovetter's work.

Human and social capital simultaneously influence immigrants' job-finding and well-being in labor market. Human capital theory could help explain why certain immigrants with high human capital are still trapped in the low-skilled labor market, and which forms of human capital are more important to immigrants' job-finding than others. Social capital could explicate not only the job-finding process but also the job transitions of low-skilled immigrants (Sanders, Nee, and Sernau 2002). However noticeably, the current human capital theory is inadequate to explain the specific human capital's impact on the well-being of immigrants. Many scholars point out that English proficiency and educational attainments positively influence immigrants' wages (Zhou and Logan 1989; Zhou 1992; Chua 2002), yet few of these theories discuss which form of human capital has the primary impact, and which does not significantly influence immigrants' economic returns or social status, and this work is willing to resolve this problem.

\section{Job Transitions in the Labor Market}

The theory of job transitions contends that across a succession of jobs and over time immigrants are inclined to change their jobs from informal/ethnic domains to formal/open domains which offer higher wages and better working conditions, and that the job transitions among immigrant workers will involve routine moves across ethnic boundaries, fields of work, and sectors of the labor market (Nee, Sanders, and Sernau 1994). The underlying idea of this theory is that immigrants' social mobility follows an upward trajectory with the accumulation of human capital. For example, the more jobs one has been working at or the longer time one has been living in the host country, the higher social mobility one may obtain. Since the more jobs one has done before and the more working experiences he or she could attain, the accumulation of human capital enables immigrants to be more competitive in the labor market. Consequently, the wage and working condition will be improved accordingly, and the wages and working conditions may even converge to those of natives' (Borjas 2006; Mane and Waldorf 2013). Also, the longer time one has been living in host countries provides immigrants with more opportunities to become familiar with the labor market (Sanders, Nee, and Sernau 2002). Additionally, immigrants are able to obtain more job-relevant information from the new ties they have built during the time when they were living in host countries, which allows immigrants to move into cozier occupations or more lucrative jobs.
The theory of job transitions plays a crucial role in illustrating the pattern of immigrants' mobility in low-skilled labor markets, and the increase of immigrants' human capital and social ties is the key factor inducing immigrants' mobilizations in the labor market. But, noticeably, the upward mobilization is not guaranteed, and there are some preconditions that must be fulfilled before successful mobilization. Among the various forms of human capital, English proficiency has salient impact on immigrants' upward mobility: research suggest that workers with little English and few other skills may be trapped in jobs with few prospects for career mobility (Nee, Sanders, and Sernau 1994; Chin 2005; Zhou 2009). Therefore, English proficiency is a necessary precondition for immigrants' upward mobilization. Applying the theory of job transitions into the lowskilled labor market context could help explain the stagnation of some low-skilled immigrants' mobilization. Although some immigrants might have been living and working in host countries for a long period, due to lack of English language skills, jobs transitions may not always give rise to higher wages or better occupations. The theory of job transitions provides perspectives not only on the trend of immigrant mobilization in labor markets but also on the preconditions of mobilization.

These theories have all discussed the influence of the immigrants' human and social capital on their well-being in labor market. However, most of these theories' conclusions are not from a micro perspective in the sense that they assumed the human or social capital as a single variable rather than consisting of combinations of specific factors, and they did not explore how specific forms of human and 
social capital operate in the co-ethnic labor market, and which form of human and social capital is more important for the immigrants' job-finding and job transitions. In this study, I will examine these unsolved questions.

\section{Data}

My data were derived from sixteen in-depth interviews with low-skilled immigrants and observations in employment agencies. Fifteen interviews were conducted with immigrants who were seeking job opportunities, and one was with the head of an employment agency. Six of my interviewees had obtained working permission from the U.S. government, and the other immigrants were all undocumented immigrants who were seeking political asylum or other channels to obtain working permission or citizenship in the United States. Three participants obtained a Bachelor's degree, and only one had a Master's degree. For the rest of the participants, three attended high school or the equivalent professional school, and others ended up with a junior high school education. Four of sixteen interviewees came from rural area in China, eight were from secondary cities, ${ }^{1}$ and four were from metropolises such as Beijing, Shanghai, Wuhan, and Harbin. Their occupations in China varied extremely from medicine doctor, college professor, and civil servant to taxi driver, self-employed businessman, and farmer. Only three of the interviewees had fair English proficiency, which meant that terms of the economic growth, but are more developed than other cities within China. they could conduct basic conversations in English, though their pronunciation and grammar may still be problematic, whereas the rest of the interviewees could recognize a few English words and were incapable of communicating in English. Except for one, all of the other immigrants had at least one working experience in the United States, and all of their previous occupations were low-end jobs with an average monthly wage of around 2000 to 2500 dollars.

In terms of the observations, I visited all the employment agencies in Flushing, and a majority of them in Manhattan's Chinatown. These employment agencies are private and are run by earlier Chinese immigrants, most of whom have migrated to the U.S. more than ten years ago. The primary business of these agencies is distributing job opportunities to their customers, such as introducing immigrants to the positions they collected from employers. The site of employment agencies abuts each other; typically they cluster in the primary business streets of the Chinese community with inconspicuous signboards which bear their names in Chinese characters. Most of these agencies are no larger than 200 square feet and with only one to three staff, who are also the heads of the agencies. The employment agencies in Chinatown of Manhattan always have a big counter within them, which to some extent makes them look like banks or bureaucratic departments. Typically, a huge transparent glass wall or iron fence was erected above the counter, which was also pasted with several stickers with employment information, to separate customers and staff. Whereas Flushing's employment agencies usually have a wide-open layout, may not be as orderly as those in Chinatown of Manhattan in the sense that the staff has only one little office desk, and customers freely sit beside the staff to ask questions directly. Most important, due to the wide open space in Flushing's employment agencies, people can linger in their waiting areas for longer time, which enables interactions that are much more frequent than those in their counterparts in Manhattan; sometimes even the bosses would join in on the customers' interactions.

There are five agencies close to Flushing's main street, and the employment agency I visited most frequently was the one owned by a female Chinese immigrant, Miss Lee, who obtained her U.S. citizenship twelve years ago. Miss Lee's agency is not large, and she is both the only staff and the owner of this agency. Her agency is located at the second floor of a low building with extremely narrow stairway. The reason I lingered in Miss Lee's agency more frequently than in others is that her agency has a larger waiting area, in which more Chinese immigrants could stay. More customers meant more opportunities for them to talk to each other, thereby there were more interactions in this agency than in other agencies, which also provided me with more data on the target group of my research. Miss Lee was affable and conversable in the sense that she is fond of participating in her customers' interactions, which enables me to explicitly observe how she distributed job opportunities to immigrants.

Although my observations were mostly conducted in one of these employment agencies, I visited all of them as long as I went to Flushing or Chinatown. When I was in the employment agency, all the job-relevant phone calls the boss had made and her most of the job-relevant conversations with customers were tracked.

\section{Methods}

The two main methods of this study are semi-structured qualitative interviews and ethnographic observations conducted in a nearly one-year period. I began visiting Flushing and other Chinatowns in New York City since September 2013, and the numerous employment agencies caught my attention. In the next seven months, I spent three days per week on average visiting those employment agencies to perform observations and to recruit potential interviewees. My ethnographic observations were conducted in one employment agency, since it is one of the largest employment agencies in Flushing with relatively more customers. These employment agencies are close to each other, and immigrants usually visit all of them one by one. As this employment agency had a spacious waiting area, more immigrants would sojourn in here for longer time than in other employment agencies. Most of the time in the employment agency I was quietly sitting in the waiting area with other immigrants who were waiting for job opportunities. I observed the interactions among immigrants and those between immigrants and the boss, and I especially focused on how the job opportunities were distributed in the employment agencies, people's perceptions of the job opportunities, and their living situations in the labor markets. I anticipated that from their interactions with each other certain 
hidden rules of the labor market could be uncovered. My interviewees were recruited from the waiting immigrants in employment agencies. Interviews revolved around semi-structured questions addressing immigrants' individual human capital, social capital, their working history in China, their working experiences in the U.S., and opinions on their living circumstances in the United States. Aside from the structured questions, some of the questions were asked variedly based on responses from participants.

My arguments were formulated through my empirical findings from interviews, most of which are the perceptions of immigrants to the labor market, and sometimes these perceptions might be too subjective to be perfectly convincing. Since the employment agencies are the place in which jobs were distributed, and in which employers' requirements were reflected and embodied, my method of reconciling the danger of subjective discourse from my interviewees is to compare interviewees' narratives and my own observations in employment agencies. Through this way, the labor market no longer merely exists in immigrants' perceptions, but also in the reality in which immigrants were embedded and engaged.

\section{Analysis}

The purpose of this study was to find what factors affect immigrants', especially newcomers', job-finding and job transitions in the low-skilled labor market, how these factors affect immigrants in labor market, and the mechanisms behind these factors.

\section{English Proficiency}

Although Flushing provides a co-ethnic environment for newcomers, in which newcomers and immigrants without any English proficiency could still survive and have their demands met by Chinese businesses, living in Flushing is different from working in Flushing. As the target groups of these Chinese businesses are not solely Chinese immigrants and these businesses also serve other ethnic minorities and customers outside Flushing, some jobs in Flushing still require immigrants to have certain degree of English language skills. However, not all occupations require employees to have English language skills, and these exact occupations are the ones which provide abundant opportunities for low-skilled newcomers who do not speak at least fair English. The participants of my interviews mostly (13/16) did not possess fair English language skills and could only understand very simple words. One of my respondents described his English language skill, which was common among my interviewees:

I could not speak English logically. Before I came into the U.S., I studied English for only one month, and all I know is simple words, such as "cherry," "apple," I could hardly speak in an intact sentence, I basically know nothing about English grammar.

This low degree of English proficiency has largely restrained not only immigrants' job opportunities but also their wages after they were recruited. In Flushing, some jobs require employees to communicate with customers face to face, or respond to phone calls from customers, which may occasion- ally be in English, and some agencies recruit both employees who could speak English and those who could not. For instance, cashier and waiter are occupations that might need to communicate with customers face to face in English, and construction workers, delivery workers, and workers in the back-kitchen of Chinese restaurants do not need any English language skills at all. According to my observations, only few jobs require employees to have English language skills, but these jobs could offer higher wage for employees. Some excerpts could confirm my observations:

Interviewer: Which skill do you think is the most necessary for you right now, and why?

Interviewee: English proficiency, definitely. If you could not speak English, your wage would be 7 dollars per hour, and if you can speak fair English, then your wage would be raised to $30-40$ dollars per hour, that's the difference.

When asked about his own job-finding situation, Kwong, who used to be a busboy, told me:

You [referring to himself] could only work in the restaurant, since only jobs in the restaurant don't ask you to speak English, I mean, in the kitchen area. It is different if you work at the counter or be a waiter, and in the kitchen, you don't have to talk to customers. The main job opportunities for us are the Chinese restaurants. I am not in the same situation as you are, your students could speak good English, and have knowledge. There are other ways for you. If you want to find a job, you would not come here, you can work in the law firm, and make big money, we are different.
In a low-skilled labor market, requiring English language skills does not necessarily indicate that one job is of a higher status than other jobs, but reflects more the economic logic of low-skilled labor. If one serves customers face to face, he or she has the opportunity to receive tips, which directly increases their income. This discrepancy was saliently reflected in the jobs in restaurants. One immigrant who used to be a laborer in a back-kitchen said to me:

I cannot do any other jobs, I could not speak good English and have not high educational degree, but if you can speak good English, you can work as a busboy in the restaurant, and you can receive tips, and the wage of waiter could be 3000 dollars and more [monthly rate], whereas my wage is only 2500 dollars.

My observations in different employment agencies indicate that the English language skill is not a necessary condition for immigrants to obtain a job. For men, the advertisements in employment agencies $80 \%$ are from jobs in back-kitchens, construction teams, and delivery companies, which do not require them to communicate with customers face to face. For women, the available jobs in employment agencies are primarily childcare jobs, and customers who came in contact with these Chinese employment agencies are also mostly Chinese middle-class families, so it is unnecessary to possess English language skills, as well. In the low-skilled labor market like Flushing, possessing a certain degree of English proficiency would probably increase one's wage by some hundred dollars, but since most of the jobs do not require immigrants to have English proficiency, there is no urgent need for newcomers to be able to 
speak English. Therefore, to some extent, English proficiency is not a necessary precondition for finding a job in a low-skilled labor market like Flushing, but possessing English proficiency is a salient advantage for increasing income. In terms of job transitions, immigrants who have some level of English proficiency are capable of finding better jobs as they become familiar with the job market, but it does not mean that it is easier to find a job. Since possessing English language skill is an important form of capital for them, many immigrants do not want to engage in low end jobs, which account for the largest proportion of the opportunities pool of jobs. As a result, many only look for opportunities which offer a higher wage and shorter working hours, which are relatively scarce in the low-skilled labor market. Han, who used to be a faculty member at an art school in China and could speak fluent English, was seeking a job in an employment agency when I met with him. Han told me:

Because I could speak English, I will never want to work in the back-kitchen. Working in the back-kitchen is laborious, it will ruin my hands, you have to work there for ten or more hours one day and with only lower than 2000 dollars per month. Even if I could not find a job right now, I would never work in the back-kitchen, I would prefer to just wait. I just do not want to waste my capability of English.

Therefore, in a low-skilled labor market, English language skill is not a necessary precondition for job-finding, since in the co-ethnic environment, more, and most of, job opportunities do not require English language skills. Immigrants who possess English proficiency tend not to work in those oc- cupations which do not require English language skill because they think these opportunities would render their advantage pointless. Due to the scarcity of ideal job opportunities for those immigrants, English proficiency is not helpful for job-finding or job transitions to these people. But, once one starts working, English proficiency saliently affects immigrants' wages and working hours.

\section{Educational Achievement}

Usually, educational background is a basic measurement for applicant's capability in the labor market, since educational background reflects one's ability to learn and capability from formal institutions in society. However, in Flushing, educational achievement seems not as significant as it was in outside labor market. The primary reason is that job opportunities in Flushing mostly do not ask for a strong educational background, and since most of these opportunities provided by the employers in Flushing were simple manual labor, these jobs could be accessed by anybody. Of my 16 informants, only three had a Bachelor's or above degree, most (10/13) had not even attended high school. At the employment agency I was observing, not even once did the boss, Miss Lee, ever ask about the educational background of job-seekers. When I asked about the importance of educational achievement in job-finding, Cheng, a former taxi driver in China, remarked:

The diploma is completely unimportant here, I have been to so many employment agencies, and nobody has ever mentioned my educational background, employers here will not anticipate people have strong educational background, or they will not recruit people from here. Just think about it, why will you recruit a cook or a worker who has a Bachelor's degree?

Another reason that educational achievement is unimportant to immigrants is the limited transferability of educational capital from their countries of origins to the U.S. (Sanders, Nee, and Sernau 2002). One job-seeker, Yin, who has a Bachelor's degree from China, commented:

There is an old saying in China: Those who have no practical use are the literati. My major in college was Russian language, I could speak Russian instead of English. Russian language is totally useless in here.

Since the educational capital Yin holds is not in popular demand in the Flushing's labor market, he could not find a job through the educational capital he has. Some other educated immigrants, who studied popular majors in a Chinese college, still face the problem of transferability as their diploma or major is not acknowledged in the U.S. Liu, a traditional Chinese medicine doctor in China, now works in a pharmacy store in Flushing, and he remarked when I asked him why he did not find a job in the hospital:

First of all, I am a Chinese medicine doctor, I am in a different system from the doctor here. Secondly, if I would like to be a doctor here, I need a license, and I need to graduate from a medicine school to get a doctoral degree, it is hard for people at my age to do that. I mean, if I was younger, I probably would consider about that, but now I am not that young, I have no money and energy to learn from zero.
Aside from the unrecognized educational capital, another obstacle for Liu in finding a corresponding job is his inadequate English language skill. Liu's ideal job is being a private doctor for a rich family in the U.S., and he has received several offers from middle-class White families, but he is concerned that his inadequate English proficiency will affect the diagnoses, so finally he turned down all these offers. Now he is an unlicensed pharmacist who sells health products and provides simple diagnoses for the customers. He earns less than 2000 dollars per month and has to care for his two daughters. Although he has a Bachelor's degree in China, due to the lack of recognition of this degree in the U.S. and adequate English language skills, his Bachelor's degree is pointless to him, and even if his job does not seem as laborious as other manual labor jobs in Flushing, his economic pressure is still huge. Therefore, without a recognized diploma and fair English skills as preconditions, many immigrants view their educational background as just a piece of waste paper.

Another example is Han, a former professor of drama history in China, who graduated from a famous Chinese university and could speak fluent English. Now he is a bellboy in a motel. When I asked him why he did not find a corresponding job in the U.S., he said:

Of course I would want to [find a corresponding job], I would want to work in a theater or in a college, but I have not gotten a legal status right now, so those jobs are unavailable to me. As soon as I get the legal status and working permission, I will quit this job and find new jobs outside here. 
Therefore, because the low-skilled labor market generally does not offer job opportunities that require a high educational background, educational attainments are unnecessary and useless for finding a job within Flushing. For job transitions, educational achievement would be helpful, especially for upward mobilization in outside labor markets. However, several preconditions must be fulfilled in the first place: a transferable educational degree, fair English language skills, and legal immigration status. As all these requirements are essential for American labors, the co-ethnic environment may shelter laborers who do not possess these capabilities, and educational achievement may be a form of human capital solely relevant in the mainstream labor market. Therefore, educational achievement is a supplemental type of human capital for immigrants who are seeking jobs both in Flushing and in the mainstream labor market.

\section{Immigration Status}

Legal immigrants refer to immigrants who have attained permanent residency in the U.S., or at least permission to legally work in the U.S. Of my sixteen respondents, five had attained legal status either through marriage with U.S. citizens or through successful application for political asylum, and the rest were applying for political asylum to get a legal status. In 1986, the Immigration Reform and Control Act (IRCA) was implemented, which aimed to control the population of undocumented immigrants (Todaro and Maruszko 1987). According to the IRCA, any employer who knowingly hires or recruits undocumented immigrants would be punished. Research suggests that this Act resulted in the employers' discrimination against foreign ap- pearance (Pérez and Muñoz 2001). When some employers dared to hire undocumented immigrants, these immigrants' wages were lower than other employees who had legal status, since the employers claimed that the lower wages were compensation for the risks they were taking in hiring undocumented immigrants (Massey 2007). So what is the influence of immigration status on immigrants' job-finding and job transitions in Chinese ethnic labor market?

During my observation in the employment agency, every interaction I recorded between the boss, Miss Lee, and the immigrants involved the question of "whether you have legal status?" Once Miss Lee received a phone call from an employer who wanted to recruit a busboy to work in a restaurant in a big shopping mall in Flushing. According to Miss Lee, this job was "very good," since it required the employee to work only 10 hours a day (which is fewer than the standard length of working hours in Flushing), and the monthly wage amounted to 2000 dollars, and was paid in cash with no need to pay taxes. Additionally, the busboy could receive tips which would increase the monthly wage by $400-500$ dollars. After a while, one young Chinese man, who was around 24 years old, came in and said that he needed a job. Miss Lee asked his personal information, such as where he was from, how old was he, and whether he had worked in Flushing before. It seemed that this young man met the requirements of the busboy position, and Miss Lee mentioned the job to him:

Your qualifications are excellent, this busboy job is very suitable for you, easy work and fair wage. Wait, do you have working permission?
The young man said no, and Miss Lee remarked:

Well, I will confirm with the restaurant, but I think in such a big mall, most of the shops only recruit legal immigrants, but we will see, just wait here for a second.

Then she called back to the restaurant, and the employers' answer was negative. Miss Lee said to this young man:

No, I can't help, they only want a legal one, I think you should work out your legal status first, or you can hardly get this kind of good jobs, you are young, it should be not hard for you to get legal status. It's a pity, I thought you are very qualified for this job.

This example shows that some occupations in Flushing require employees to have legal status, either because of these occupations are all located in big malls, which always have internal contracts with the shops that ask the employers to conform to the law, or because they are more exposed to the public, which may easily incur the attention of law-enforcement. Although this young man was well-suited to this job, he could not obtain it due to the lack of legal status. Miss Lee once remarked: “Those jobs which require legal status may not be good jobs, but those good jobs require legal status," which delineates the impact of the legal status requirement in the labor market. While many job opportunities in Flushing do not require immigrants to have legal status, a legal status means that immigrants have more choice in the labor market, and can find a good job more easily.

However, for women, the legal status impacts the job-finding process differently. Most jobs avail- able from employment agencies for women are exclusively nanny jobs. These jobs openings are not public and caregivers are instead recruited by families. In my observations at the employment agencies, female job-seekers are almost evenly split between those with and without legal status. When Miss Lee recommended a nanny to an employer, she never mentioned the immigration status to the employer, in contrast with her introductions of male immigrants to employers. Since there are more jobs with differing requirements for immigration status available for male immigrants, having legal status would be a salient advantage for male job-seekers. However, for female immigrants, due to the scarcity of available jobs that often do not require legal status, having a legal status does not increase women's likelihood of finding a job. In terms of job transitions, since immigrants who have legal status have more job opportunities, they can easily shift into better occupations, and at the very least, it is easier to change to a new job. For female immigrants, due the unimportance of immigration status to the labor market, having legal status is not helpful for female immigrants to find a new job.

\section{Working Experience}

In this section, I will explore the influence of immigrants' former working experiences to their job-finding and job transitions. When I was at the employment agency doing my observations, the word "rookie" (shengshou), which refers to newcomers who do not have any relevant working experiences in China, was frequently used. The counterpart of "rookie" is "veteran" (shushou), 
which refers to those who have relevant former working experiences. Cheng, a former taxi driver in China, is a typical rookie. As of our interview, Cheng worked in a construction team, and when I asked whether he had relevant working experiences in construction, he remarked:

No, I have never thought that I would be a construction worker, you know, in China, the construction workers are the most bottom people in the society, nobody will work in a construction team if he has other choices, I knew I probably could no longer be a taxi driver here, but I never imagined that I would be a construction worker here.

Yuen, who is a veteran, has worked in the back-kitchen of different restaurants in Manhattan's Chinatown for many years. He described the difference between having working experiences and not having experiences:

Rookies can only be a laborer in the kitchen, doing things like cleaning, washing dishes, and other miscellaneous works. Since a cook needs professional skills, a waiter needs to speak English, if you have neither of these skills, you can only be a laborer, but there is a difference between the rookie laborer and the veteran laborer. I was a veteran laborer for many years, the veteran laborer could earn almost 500 dollars higher monthly wage than the rookie laborer. Actually, some bosses would prefer to hire the rookie laborer, since they do not need to pay more money for this simple work, no matter how many years you have been a laborer, you are still a laborer, you are still cleaning dishes, it does not mean that you can clean better than others.
The transferability of former working experiences is also a problem. Since the labor market in Flushing provides much fewer job choices than the outside labor market, the few job choices, which are concentrated mostly in the restaurants, construction teams, or supermarkets, seriously constrain the transferability of immigrants' former working experiences. Only one of my respondents, who was a cook, had the same occupation as the one he had in China, and none of the rest could practice their former jobs in the U.S. Therefore, these immigrants, who do not have former relevant working experiences and usually are low-skilled or facing the non-transferability of educational achievements, were referred to different low-end jobs within Flushing. Having former work experience also was not an important indicator for finding a job, since most immigrants could not perform the equivalent jobs in the U.S., whereas relevant work experience was often necessary. The cook could earn 3000 dollars per month, and he proudly remarked:

I could easily find a job, at least easier than the laborers, since I have essential skills, everyone could be a laborer, but not everyone could be a cook.

The cook's comments confirm my observations in the employment agency: most of the male immigrants who were sitting in the waiting area for a whole afternoon or a whole day were all applicants for laborer positions. However, whenever a cook visited the employment agency, Miss Lee would always have available opportunities for him, and if the cook was satisfied with the job offer, they would often get hired. Most cooks did not have to wait at an employment agency, and if they could not find a job at one employment agency, they will then visit others nearby until they find a satisfactory job.

Work experience is differentiated by those with professional skills and those without professional skills, but the precondition is that work experience must satisfy the current demands of labor market, which means that the experience must be "relevant." Therefore, in terms of job-finding, immigrants who have relevant work experience and professional skills have a significant advantage compared to immigrants who have relevant work experience, but without professional skills. Immigrants who have relevant work experience without professional skills do not have an advantage compared to immigrants who have only unrelated work experience in term of finding a job, since employers usually prefer to hire those without work experiences to reduce the cost for low-skilled positions. However, once the veteran immigrants find a job, they may enjoy a higher income than rookie immigrants. For female newcomers who are applying to childcare jobs, most of them are not single, and nearly all women have experiences of rearing their own children. Although these women may have held different jobs before, they are competent at caring for children and performing housework, and having related work experience is not essential for finding childcare jobs. In terms of other available low-skilled jobs for women, such as jobs in nail salons, the importance of prior work experience is similar to that for jobs targeted towards male immigrants.

Former work experience plays an interesting role in the job transitions. Since every time an immi- grant changes his or her job, he or she might have accumulated a certain degree of experience, but this impact may only exist in the transition from the first job to the second job, and a longer work history may not matter as much over time. The difference between the rookie and the veteran is not determined by the length of working years, but rather by the number of relevant working experiences they held in the past. For an employment agency, if a client has ever had a similar job, they could be considered a veteran, even if he or she has only worked at that job briefly. Therefore, for immigrants who have already transitioned from their first jobs to their second jobs, the advantage of relevant working experience is no longer salient.

\section{Social Capital in the Low Wage Labor Market}

In this section, I will analyze how social capital affects immigrants' job-finding and job transitions in a low-skilled labor market. Generally, social capital could be defined as the investment and use of embedded resources in social relations for expected returns (Lin 2000). In other words, social capital refers to the resources that people may access through their social contacts. For job-finding, opening-positions information is one of the most important resources, as immigrants who had more knowledge of open positions, as well as better job information had a better chance of finding a job than those who knew little or had no job information (Nee, Sanders, and Sernau 1994). In order to study the impact of the social capital, it is necessary to take immigrants' social contacts and social ties into consideration. Therefore, social capital in the labor market refers to the efficient social ties that could provide 
substantive assistance for job-finding. The social ties of immigrants determine how much information immigrants could get access to. Therefore, to understand immigrants' social capital, I will first focus on how social ties enable immigrants to obtain access to their jobs, and secondly, how these social ties affect immigrants' job-finding and job transitions.

\section{The First Job}

Since nearly all of the interviewees (15/16) had work experiences in the U.S., I asked them how they obtained their first jobs in the U.S. The first jobs of these 15 immigrants were mostly obtained through (12/15) introductions by their friends, family members, or co-township organizations, who immigrated earlier than they did. Liang was searching for a job in the employment agency when I met him, and his first job in the U.S. was in a construction team. This job was introduced by a friend who was also working in the same construction team. When discussing his first job, Liang remarked:

My first job was introduced by a friend of mine, he has been working in the construction team for many years in the U.S., and he is quite familiar with the boss of that construction team. Before I came here, he promised me that he could help me find a job here, so I came. I am grateful that he introduced that job to me, although that job is not a very good job. The biggest problem with the construction team is that the income is unstable, since this work is seasonal. In the summer, there is a lot of work to do, and you can earn a fair income, like fifteen dollars per hour and tips, but in the winter, sometimes you cannot get even one job for three months, besides, it is extremely laborious, I am old, I cannot carry heavy cargo up and down, this job is not suitable for me, I want a job that is stable and not that laborious, so I quit after working there for one month.

Ping, a female Chinese immigrant, is now a nanny in a Chinese family. She came here four years ago and her first childcare job was introduced by a woman from her hometown. She remarked:

You know, there are some hometown associations in Flushing, earlier immigrants could share their living and working experiences in the U.S. to the new members. One friend of mine introduced me to their association, she told me that I could find a job there, and the members there are all old ladies who are from [their city of origin]. My first job was introduced by a sister [referring to a woman from the same hometown] there, she was leaving for China at that time, and her employer wanted her to recommend a replacement, and I was seeking a job, so she asked me whether I wanted to take that job, and I just took it.

For Liang and Ping, their first jobs were all obtained through introductions by their acquaintances in the U.S. These friends or acquaintances are one aspect of their social capital in the sense that these acquaintances provide newcomers with employment information or introduce them to the larger local networks that may contain more job opportunities. The interesting phenomenon is that the jobs of the newcomers who found them through their social capital are always the same as those of their referrers. Therefore, social capital may improve the newcomers' chances of getting a job in the labor market, since it provides the newcomers with important job information and new social ties. However, given that the first job opportunities of the newcomers are mostly the same as those of their acquaintances, it is not guaranteed that the first jobs are stable for the newcomers in the sense that the newcomers have limited choice in their first jobs and sometimes they might do not like their first jobs.

For those who did not find their first jobs through their social networks, their first jobs were always introduced through more impersonal sources such as employment agencies or newspaper advertisements. The primary reason for immigrants to use these channels to find their first job was that they generally lack efficient social ties in the U.S. Liu, the traditional Chinese medicine doctor, obtained his first job through one employment agency:

My first job was delivering cargo for a Chinese supermarket, I got this job through Miss Lee's employment agency. Yes, I have several college classmates in the U.S., some of them are working in law firms and big corporations. I feel ashamed to ask them to offer a job to me, besides their jobs might not be suitable for my capability, as well, so I would rather find a job in Flushing.

The college professor, Mr. Han, has an uncle in New York. His uncle is 80 years old, and used to be a doctor in the U.S. for many years. When I asked him why he did not ask his uncle to find a job for him, he said:
I am an independent man, I don't want to rely on anyone. Moreover, my uncle could not find a job for me anyway, he is such an old man, and he is that sort of isolated old man, he barely talk to anybody, even his daughters. If I want to survive in the U.S., I could not rely on him, I mean, he could give me some money now, but how long he could afford my expense? I must rely on myself.

Although the reason that Liu and Han did not request help from friends or family members is because they want to keep their dignity, another reason might be that these social ties are not efficient for their job-finding at this moment. Liu's friends actually are among the middle-class and are working in high ranking occupations in the U.S., but Liu's current English proficiency and professional skill set are not adequate for the high ranking jobs that his friends might offer him. However, if he wanted to find a job in Flushing, a relatively low-skilled labor market, his middle-class friends were unlikely to be able to provide assistance. Han faced a similar situation-although his uncle lived in the U.S. for many years, Han could not get effective help from his uncle because of his uncle's old age and social isolation, rendering this social tie ineffective, as well.

The utility of social ties varies and depends on their efficiency. Efficient social ties do not mean the strength of ties in the notion of Granovetter's weak ties theory. Granovetter's theory might be suitable to explain the networks in a diverse and mainstream labor market, but in a co-ethnic low-skilled labor market, while each job-seeker might have different networks, these networks are mostly embedded in 
Flushing, which means that these networks are essentially similar to each other in utility. Therefore, no matter if these different ties are strong ties or weak ties, the strength of ties is not the determining factor of job-finding in Flushing. The essence of the problem is whether or not the social ties are efficient, which is more relevant to Burt's contention of the structural holes, that is, opportunities would be available only when the holes among networks were bridged (Burt 1992; Sanders, Nee, and Sernau 2002), which also indicates that for people in different networks, if the holes between different networks are not bridged, then the assistance could barely transfer from one network to another, which may lead to any existing social ties pointless. For many interviewees, some social ties are inefficient because the interviewees themselves do not possess adequate capability to bridge the holes between themselves and the high end networks or other available networks are not actually helpful, and they do not intend to bridge the gaps between networks at all. Therefore, efficient social ties for low-skilled immigrants are those in the similar networks with the informants, and those which provide accessible information rather than desirable and prestigious but not feasible opportunities.

Research suggests that reliance on social ties is most common for moves into jobs of low occupational prestige that have low human capital requirements (Sanders, Nee, and Sernau 2002). Overall, social ties may provide potential job opportunities for job-seekers in Flushing, especially for immigrants' first jobs in the U.S., but social ties' utility is not guaranteed, as the utility depends on whether the social ties are efficient or not.

\section{Job Transitions}

Among the 15 out of 16 participants who had work experience in the U.S., all of them also experienced job transitions. Usually, immigrants' first jobs did not last very long-among these participants, the longest first job lasted for 6 months, and the shortest only lasted for 3 days. Not all job transitions were voluntary or desired by the immigrants, as sometimes employers fired immigrants. In this section, I focus on social capital's influence on immigrants' job transitions rather than the reasons for immigrants' job transitions.

All interviewees were recruited at the employment agencies, and through my interviews with them, one interesting phenomenon emerges. After their first jobs, immigrants no longer mainly rely on their social ties to find a new job. Liang worked in several different occupations after his first job in the construction team, and every new occupation after the first one was introduced by the employment agencies. When I asked the reason why he did not ask his friend for help, he remarked:

[Asking for help] is unnecessary, I worked in the construction team for two months, and after that I have adapted to the life here, and I know how to find a job by myself, I know where those employment agencies are, and which newspapers have employment advertisements, there is no need to solicit help from my friends. It is embarrassing to ask them for help. I mean, for the first job, since that was your first time in the city, it is reasonable to ask them for help, but people will feel annoyed if you keep asking them for help. If you ask friends for help, some other day you have to pay back. And I don't think they have better job opportunities for me, if they have they will go, I don't want to work in the construction team anymore.

Kwong's first job was introduced by his father, who immigrated before him, but he quit that job after a couple of months, and was also looking for new jobs in the employment agencies:

I do not need my father to introduce jobs to me, I am an adult and I have lived in Flushing for several years, I am familiar with here, my father may not know more than I know, I could find a job by myself.

Although most immigrants have some efficient social ties in the labor market given that these ties were often a factor in the decision to migrate to a totally new environment, there are several factors that may cause the social tie to lose efficiency. First, over time, when immigrants become familiar with the labor market, they will acquire their own knowledge of where to find a job, and how to assess the quality of a job opportunity. As newcomers become familiar with local circumstances, this advantage of earlier immigrants from their knowledge of Flushing vanishes. Therefore, the original social ties are no longer meaningful to newcomers, since newcomers are now informed, as well. The duration of adaptation varies, some people may take longer time to be independent and adapt to circumstances (which means not to rely on original social ties), and personal willing plays a significant role in this setting, so time is not a very suitable measure in this case, and frequency of using social ties would be better for explaining newcomers' behaviors. From my ob- servation in Flushing, using original social ties for one or two times are the most common cases for newcomers finding jobs, but fewer interviewees use original social ties finding jobs for more than 3 times. It seems original social ties lost its attraction to newcomers after it was utilized for 4 times and more. The second factor is that using "weak ties" is costly. Although having different social ties amounts to having control over a certain degree of social capital, using these social ties is not free, as an equivalent exchange is often expected. For this reason, when newcomers have gained enough knowledge about the labor market, they do not want to use their social ties, since they feel they are indebted to their benefactors. Although some social ties may provide newcomers with important job information, these ties are still located within similar networks as those of newcomers; in other words, the information controlled by earlier immigrants is always relevant to their own occupations, and if newcomers are not suited to the occupations of earlier immigrants, they can transfer into a different field, and the once efficient social ties became unhelpful. Therefore, when finding the first jobs, efficient social ties are helpful, but the efficiency declines dramatically after immigrants' first jobs.

\section{Discussion and Conclusion}

From my interviews and observations in the Flushing Chinese ethnic enclave, I find that English language skills have little influence on immigrants' job-finding, since Flushing is a large co-ethnic community and provides a large number of occupations that do not require employees to speak any English. Therefore, for both finding a job and job transitions, 
English proficiency is not a distinct advantage, and sometimes may even restrain immigrants from obtaining a job. This outcome is because immigrants who can speak English always have higher expectations of their prospective jobs, and the opportunities of which are much fewer than that of the lower-waged jobs that do not require English proficiency. However, once immigrants find a job, those with English language skills will earn more wage than their counterparts who do not speak English.

Concerning educational attainment, Flushing is inundated with low skilled job opportunities, and most opportunities that are suitable to newcomers are menial labor and do not require educational attainment. Additionally, educational attainment in immigrants' countries of origin may not be transferable in the U.S. Therefore, higher educational attainment might be an advantage outside of Flushing, but newcomers' educational attainment does not affect their job-finding and job transitions in the Chinese ethnic enclave.

Immigration statuses influenced job-finding and job transitions differently for male and female immigrants. Because men had more job choices in the labor market, which also means that men have to face diverse requirements of different jobs, those jobs that required legal status provided employees with higher wages and a better job environment. Therefore, having legal status significantly facilitates male immigrants' job-finding. For female immigrants, since they had fewer job choices, and these job choices did not require legal status, immigration status did not have much influence on female immigrants' job-finding and job transitions.
Former working experiences may facilitate immigrants' job-finding and job transitions, but this influence only occurs for job opportunities that require professional skills, and depends on whether these former professional skills are relevant to the demands of the labor market.

All in all, the most useful forms of human capital for immigrants to find a job in Flushing are those relevant to the demands of the labor market. Here, relevant former working experience in demand jobs is the most helpful form of human capital for immigrants' job-finding. For instance, the interviewee who worked as a cook could easily find a job in a restaurant in the sense that they can select from several choices, whereas immigrants without relevant working experience may not have this range of choices available to them. As Kwong stated, it is the jobs that choose immigrants, and not the reverse. For other forms of human capital, such as English proficiency, job opportunities that require employees to have English proficiency and those that do not have huge differences in their wages and quantity of opportunities. While English proficiency may not be helpful for finding a job, it is important for increasing one's income. Since an ethnic labor market like Flushing is a service-oriented community, it does not provide many job opportunities for highly educated Chinese immigrants. The highly educated who are trapped in Flushing are trapped because of either their immigration status or their inadequate English proficiency. Therefore, educational attainment is another secondary form of human capital for immigrants to find a job. It would be helpful for immigrants to own adequate English proficiency or obtain legal status in the primary labor market, in which more suitable job opportunities are provided, but not helpful in a co-ethnic labor market like Flushing.

In terms of social capital, this study found that the "weak ties" theory (Granovetter 1973) is not suitable for accounting for the mechanism of job-finding in the co-ethnic labor market, since workers who reside and work in the ethnic enclave usually share the similar social networks with each other, and the shortage of recruitment information is the primary problem that troubled nearly all the newcomers, and both the strong ties and weak ties in the ethnic enclave could not provide diverse and abundant information for the newcomers. Therefore, the strength of social ties does not adequately explain how jobs are found in the co-ethnic labor market. In the labor market, the most significant form of social capital is immigrants' social ties. Having social ties will facilitate immigrants in finding their first jobs in the labor market. However, as I have argued above, their social ties must be efficient not in the sense of the strength of social ties, but in the sense that these social ties should be able to either directly provide immigrants with a job or with more knowledge about their new environment. And as immigrants become familiar with local circumstances, combined with the unwillingness of using their social ties (usually occurs after 3 times of using original social times), the formerly efficient social ties are not as useful as they were initially. Therefore, after immigrants' first few jobs, social ties do not have much influence on immigrants' job-transitions.

\section{References}

Bailey, Thomas and Roger Waldinger. 1991. "Primary, Secondary, and Enclave Labor Markets: A Training System Approach." American Sociological Review 56:432-445.

Bates, Timothy. 1994. "Social Resources Generated by Group Support Networks May Not Be Beneficial to Asian Immigrant-Owned Small Business." Social Forces 72(3):671-689.

Becker, Gary S. 1962. “Investment in Human Capital: A Theoretical Analysis." Journal of Political Economy 70(5):9-49.

Bohon, Stephanie. 2001. Latinos in Ethnic Enclaves: Immigrant Workers and the Competition for Jobs. New York: Garland Publishing.
Bonacich, Edna. 1988. “The Social Cost of Immigrant Entrepreneurship." Amerasia 14:119-128.

Borjas, George J. 2006. "Native Internal Migration and the Labor Market Impact of Immigration." The Journal of Human Resources 41(2):221-258.

Burt, Ronald S. 1992. Structural Holes. Cambridge, MA: Harvard University Press.

Carnevale, Anthony and Stephen Rose. 2001. “Low Earners: Who Are They? Do They Have a Way Out?" Pp. 45-66 in LowWage Workers in the New Economy, edited by M. Miller. Washington, DC: The Urban Institute Press. 
Chin, Margaret. 2005. Sewing Women: Immigrants and the New York City Garment Industry. New York: Columbia University Press.

Chua, Lee-Beng. 2002. Psycho-Social Adaptation and the Meaning of Achievement for Chinese Immigrants. New York: LFB Scholarly Public LLC.

Coleman, James S. 1988. “Social Capital in the Creation of Human Capital." The American Journal of Sociology 94:95-120.

Friedberg, Rachel M. 2000. “You Can't Take It With You? Immigrant Assimilation and the Portability of Human Capital." Journal of Labor Economics 18(2):221-251.

Granovetter, Mark S. 1973. "The Strength of Weak Ties." The American Journal of Sociology 78(6):1360-1380.

Granovetter, Mark S. 1995. Getting a Job: A Study of Contacts and Careers. Chicago: University of Chicago Press.

Hagan, Jacqueline, Nichola Lowe, and Christian Quingla. 2011. "Skills on the Move: Rethinking the Relationship between Human Capital and Immigrant Economic Mobility." Work and Occupations 38(2):149-178.

Light, Ivan and Edna Bonacich. 1988. Immigrant Entrepreneurship: Koreans in Los Angeles. Berkeley, Los Angeles: University of California Press.

Lim, Zi Heng. 2013. "For Asian Undocumented Immigrants, A Life of Secrecy." The Atlantic. Retrieved May 14, 2016 (http:// www.theatlantic.com/national/archive/2013/05/for-asian-undocumented-immigrants-a-life-of-secrecy/275829/).

Lin, Jan. 1998. Reconstructing Chinatown: Ethnic Enclaves and Global Change. Minneapolis: University of Minnesota Press.

Lin, Nan. 2000. “Inequality in Social Capital." Contemporary Sociology 29(6):785-795.

Logan, John R., Wenquan Zhang, and Richard D. Alba. 2002. "Immigrant Enclave and Ethnic Communities in New York and Los Angeles." American Sociology Review 67(2): 299-322.
Mane, Kate M. and Brigitte S. Waldorf. 2013. “Human Capital and Wages: A Comparison of Albanian and Italian Immigrants." The Annals of Regional Science 2013(51):53-72.

Massey, Douglas S. 2007. “Understanding America's Immigration 'Crisis.". Proceedings of the American Philosophical Society 151(3):309-327.

Maxwell, Nan L. 2008. “Wage Differentials, Skills, and Institutions in Low-Skill Jobs." Industrial and Labor Relations Revier 61(3):394-409.

Nee, Victor, Jimy M. Sanders, and Scott Sernau. 1994. “Job Transitions in an Immigrant Metropolis: Ethnic Boundaries and the Mixed Economy." American Sociology Review 59(6):849-872.

Pérez, Sonia and Cecilia Muñoz. 2001. “Latino Low-Wage Workers: A Look at Immigrant Workers." Pp. 239-258 in LowWage Workers in the New Economy, edited by R. Kazis and M. S. Miller. Washington, DC: Urban Institute Press.

Phillips, Julie A. and Douglas S. Massey. 1999. “The New Labor Market: Immigrants and Wages after IRCA." Demography 36(2):233-246.

Portes, Alejandro and Robert L. Bach. 1985. Latin Journey, Cuban and Mexican Immigrants in the United States. Berkeley, CA: University of California Press.

Portes, Alejandro and Julia Sensenbrenner. 1993. “Embeddedness and Immigration: Notes on the Social Determinant of Economic Action." American Journal of Sociology 98(6) $1320-1350$

Sanders, Jimy S. and Victor Nee. 1987. "Limits of Ethnic Solidarity in the Enclave Economy." American Sociological Review 52(6):745-773.

Sanders, Jimy M. and Victor Nee. 1996. "Immigrant Self-Employment: The Family as Social Capital and the Value of Human Capital." American Sociology Review 61(2):231-249.

Sanders, Jimy, Victor Nee, and Scott Sernau. 2002. “Asian Immigrants' Reliance on Social Ties in a Multiethnic Labor Market." Social Forces 81(1):281-314.
Todaro, Michael P. and Lydia Maruszko. 1987. "Illegal Migration and US Immigration Reform: A Conceptual Framework." Population and Development Review 13(1):101-114.

Tsai, Jenny Hsin-Chun. 2009. “Chinese Immigrant Restaurant Workers' Injury and Illness Experiences." Archives of Environmental and Occupational Health 64(2):107-114.

Waldinger, Roger. 1993. “The Ethnic Enclave Debate Revisited." International Journal of Urban and Regional Research 17(3):444-452.

Wilson, Kenneth L. and Alejandro Portes. 1980. "Immigrant Enclaves: An Analysis of the Labor Market Experiences of Cubans in Miami." American Journal of Sociology 86:295-319.
Wong, Bernard P. 1998. Patronage, Brokerage, Entrepreneurship, and the Chinese Community of New York. New York: AMS Press.

Xie, Yu and Margaret Gough. 2011. "Ethnic Enclaves and the Earnings of Immigrants." Demography 48:1293-1315.

Zhou, Min. 1992. Chinatown: The Socioeconomic Potential of an Urban Enclave. Philadelphia: Temple University Press.

Zhou, Min. 2009. Contemporary Chinese America: Immigration, Ethnicity, and Community. Philadelphia: Temple University Press.

Zhou, Min and John D. Logan. 1989. “Returns on Human Capital in Ethnic Enclaves: New York City's Chinatown." American Sociological Review 54(5):809-820. 